\title{
THE PSYCHOLOGICAL TREATMENT OF CASES WITH CARDIAC PAIN
}

\author{
BY \\ GEOFFREY BOURNE AND E. WITTKOWER \\ From the Cardiographic Department, St. Bartholomew's Hospital and the Tavistock Clinic \\ Received August 1, 1939
}

In two papers published in 1937 (The Lancet, pp. 609 and 665) an attempt was made to assess the relative significance of emotional and organic factors in the production of cardiac pain. On examination of two groups of patients it was shown that four fifths of the first, i.e., patients with cardiac pain, as compared with one fifth of the second group, i.e., patients with cardiac deficiency but without pain, suffered from some psychological disorder before the appearance of cardiac symptoms. In a surprisingly high number of cases the cardiac pain seemed to emerge as a late component of a chronic anxiety state and its onset was often precipitated by some disturbing event in the patient's life. This sequence is familiar as far as functional pain is concerned, but it was also found in certain cases of angina of effort.

In continuance of these studies, a group of 12 patients with cardiac pain has been submitted during the past two years to psychological treatment, to find to what extent patients with functional cardiac pain might respond to this treatment, and if and how far cases of angina of effort, carefully selected because of a prominence of emotional problems in their histories, might be amenable to psychotherapy.

\section{Material : Selection of CASES}

Seven patients complained of the type of pain previously described under the label angina innocens (Brit. Med. J. 1937, I, 695). Reference to that paper will make it clear that a cardiac condition, not an intercostal fibrositis, is referred to. For the purposes of the present paper the less controversial terms functional pain or functional cardiac pain are used; another synonym is left submammary pain.

Angina of effort has as its basic lesion coronary disease, but the degree of pain is proportional to the predisposition of the nervous system to make this manifest. Psychological treatment is thus rational in cases of angina of effort with psychological abnormalities.

Seven patients with functional pain, two men and five women, and five men with typical angina of effort form the basis of the present study. One 
was a patient of Dr. Evan Bedford and the others were examined clinically and sent for treatment by Dr. Geoffrey Bourne. These cases have been selected with considerable care; previous to treatment they had all been examined carefully and had been followed for lengths of time varying, in the functional cases, from one to four years and, in the patients with angina of effort, from two to thirteen years. The type of pain had been analysed according to the classification previously described (Brit. Med. J., 1935 I, 1109). During the period before psychological treatment the diagnosis had thus been confirmed by many examinations. A number of patients were referred to Dr. Wittkower for an opinion as to their suitability for treatment and were rejected for reasons that will be explained later.

The clinical material fell into two groups, according to the type of pain present. In the group with functional pain were four cases with normal hearts, one with hyperpiesis, and two with mitral stenosis ; in the angina of effort group were two with no other severe cardiovascular abnormality, two with hyperpiesis, and one with aortic stenosis. The cases are summarized as follows.

\section{Patients with Functional Pain}

Case 1. A man, aged 54, had suffered from persistent severe pain in the left chest for three years. He had collapsed and fainted at the onset of the pain, and since then had complained of pain in the chest, radiating to the left arm. This was not quantitative to exertion or diminished by rest, but he was seen by a physician who told him that he had 'angina' and stopped him from working. On examination no cardiovascular abnormality was found, the electrocardiogram was normal, and the history of the pain was of the functional type. He was therefore reassured with regard to his heart and was referred for a psychological opinion and treatment. (See later.)

Case 2. A woman of 28 , with early mitral stenosis, had for three years suffered from pain which had, at times, been very severe. It was on the left side of the chest and was worse when she was tired. She had suffered also from attacks of pain followed by faintness, although she did not lose consciousness. In such an attack she would feel as if the end had come. On examination there was an early mitral stenosis, confirmed by X-ray, but the electrocardiogram was normal.

Case 3. A woman of 22 had for the previous five years felt pain on exertion on the left side of the chest radiating to the neck and arm. It was increased after exertion but not during it, and was accentuated by worry and fatigue. There was no cardiovascular abnormality except slight accentuation of the first sound.

Case 4. A woman of 43 had suffered for some years from pain in the left side of the chest which was at first a severe sudden stab followed by a dull ache persisting for a few minutes. Subsequently it became more persistent but was never proportional to exertion. On examination there was marked enlargement of the heart, both to the right and to the left, mitral stenosis, and auricular fibrillation. 
Case 5. A man of 39 had suffered from palpitation and exhaustion for three years. Exercise produced pain in the left side of the chest which was not quantitative to exertion. On examination he was found to have a blood pressure of $180 / 130$. The electrocardiogram showed left-sided preponderance.

TABLE I

Patients with Functional Pain

\begin{tabular}{|c|c|c|c|c|c|c|c|c|}
\hline \multirow{2}{*}{$\begin{array}{c}\text { Case } \\
\text { num- } \\
\text { ber }\end{array}$} & \multirow{2}{*}{$\begin{array}{l}\text { Age } \\
\text { and } \\
\text { Sex }\end{array}$} & \multirow{2}{*}{ Diagnosis } & \multicolumn{2}{|c|}{$\begin{array}{l}\text { Duration of } \\
\text { Treatment }\end{array}$} & \multicolumn{2}{|c|}{$\begin{array}{l}\text { Result of } \\
\text { Treatment }\end{array}$} & \multicolumn{2}{|r|}{ Follow-up } \\
\hline & & & $\begin{array}{l}\text { Phys- } \\
\text { ical } \\
\text { (in } \\
\text { years) }\end{array}$ & $\begin{array}{l}\text { Psycho- } \\
\text { logical } \\
\text { (in } \\
\text { months) }\end{array}$ & Pain & \begin{tabular}{|} 
Psycho- \\
logical \\
symptoms
\end{tabular} & $\begin{array}{c}\text { Dura- } \\
\text { tion } \\
\text { (in } \\
\text { months) }\end{array}$ & Results \\
\hline 1 & $54, \mathrm{M}$ & $\begin{array}{l}\text { Conversion } \\
\text { hysteria }\end{array}$ & 3 & 4 & Lost & Lost & 12 & $\begin{array}{l}\text { No complaints ; } \\
\text { at work }\end{array}$ \\
\hline 2 & $28, F$ & $\begin{array}{l}\text { Anxiety state, } \\
\text { and mitral }\end{array}$ & 10 & 3 & Lost & $\begin{array}{l}\text { Much im- } \\
\text { proved }\end{array}$ & 18 & $\begin{array}{l}\text { No complaints ; } \\
\text { at work }\end{array}$ \\
\hline 3 & $29, \mathrm{~F}$ & $\begin{array}{l}\text { Conversion } \\
\text { hysteria }\end{array}$ & 1 & 4 & Lost & $\begin{array}{l}\text { Much im- } \\
\text { proved }\end{array}$ & 12 & No complaints \\
\hline 4 & $43, F$ & $\begin{array}{l}\text { Anxiety state, } \\
\text { and mitral } \\
\text { stenosis }\end{array}$ & 2 & 4 & Lost & $\begin{array}{l}\text { Much im- } \\
\text { proved }\end{array}$ & 18 & $\begin{array}{l}\text { Relapsed after } \\
6 \text { months with } \\
\text { failure }\end{array}$ \\
\hline 5 & $39, \mathrm{M}$ & $\begin{array}{l}\text { Anxiety state, } \\
\text { character } \\
\text { disorder, and } \\
\text { hyperpiesis }\end{array}$ & 5 & 4 & Lost & $\begin{array}{l}\text { Much im- } \\
\text { proved }\end{array}$ & 6 & $\begin{array}{l}\text { Death after } 8 \\
\text { months }\end{array}$ \\
\hline 6 & $28, \mathrm{~F}$ & $\begin{array}{l}\text { Character } \\
\text { disorder }\end{array}$ & 4 & 4 & $\begin{array}{l}\text { No } \\
\text { change }\end{array}$ & $\begin{array}{l}\text { Un- } \\
\text { changed }\end{array}$ & 5 & $\begin{array}{l}\text { Improved later } \\
\text { and at work }\end{array}$ \\
\hline 7 & $32, \mathrm{~F}$ & $\begin{array}{l}\text { Conversion } \\
\text { hysteria }\end{array}$ & 2 & 9 & Lost & $\begin{array}{l}\text { Much im- } \\
\text { proved }\end{array}$ & 1 & At work \\
\hline
\end{tabular}

Case 6. A woman of 28 had suffered from severe shortness of breath on exertion for years and also from severe attacks of pain that might come on at any time and pass down the arm. These might be accompanied by faintness. In addition, she had a persistent left-sided ache which was worse after exertion and also passed down the left arm. On examination there was mitral stenosis with a regular rhythm.

Case 7. A woman, aged 32, had suffered for two years from pain in the left side of the chest, which was worse on exertion and was accompanied by palpitation and a feeling of weakness. On examination there was no abnormality except for a systolic murmur at the apex, conducted to the pulmonary base.

\section{Patients with Angina of Effort}

Case 8. A man of 54 had for 10 years suffered on rare occasions from a slight pain, central in position and substernal. This came on only after digging, sawing, or similar strenuous exertion. He had keen examined several times and had been told that he had heart disease, which was probably due to rheumatic fever in the past. A year before he was first seen he began to get pain frequently 
on exertion, which would go with resting and was quantitative to the amount of exertion. It was never present at rest. On examination the apex beat was just outside the mid-clavicular line and was forcible. A harsh loud systolic murmur was present at the aortic base, with a systolic thrill, and the murmur was also heard at the apex. The blood pressure was 150/110. He remained under observation for two years before he was referred for psychological treatment.

Case 9. A man of 65 had suffered for two years from a retrosternal pain that only came on as he walked and was proportional in its severity to the amount of walking. It was not increased by emotion, but was always accentuated by hills. On examination there was no increase in the blood pressure, but the apex beat was slightly displaced to the left, the heart/chest ratio being $14 / 27 \mathrm{~cm}$. The electrocardiogram showed left-sided preponderance and some notching in the $\mathrm{R}$ wave in lead II. (See later.)

Case 10. A man of 49 had had pain in the chest on exertion for two years ; it was central in position but did not radiate to the arms. This was quantitative to the amount of exertion but was also brought on by excitement. Six weeks before he had had a severe attack of pain on getting out of bed, upon which he fainted. It lasted on and off severely for a week. Since then he had been slowly improving. He was then watched for a period of two months, during which the pain remained unchanged in degree. On examination he had severe hyperpiesis, $235 / 140 \mathrm{~mm}$., the heart showed no clinical enlargement and the sounds were normal. The electrocardiogram showed no abnormality. (See later.)

TABLE II

Patients With Angina of Effort

\begin{tabular}{|c|c|c|c|c|c|c|c|c|}
\hline \multirow{2}{*}{$\begin{array}{l}\text { Case } \\
\text { num- } \\
\text { ber }\end{array}$} & \multirow{2}{*}{$\begin{array}{l}\text { Age } \\
\text { and } \\
\text { Sex }\end{array}$} & \multirow{2}{*}{ Diagnosis } & \multicolumn{2}{|c|}{$\begin{array}{c}\text { Duration of } \\
\text { Treatment }\end{array}$} & \multicolumn{2}{|c|}{$\begin{array}{l}\text { Result of } \\
\text { Treatment }\end{array}$} & \multicolumn{2}{|r|}{ Follow-up } \\
\hline & & & $\begin{array}{l}\text { Phys- } \\
\text { ical } \\
\text { (in } \\
\text { years) }\end{array}$ & $\begin{array}{l}\text { Psycho- } \\
\text { logical } \\
\text { (in } \\
\text { months) }\end{array}$ & Pain & $\begin{array}{l}\text { Psycho- } \\
\text { logical } \\
\text { symptoms }\end{array}$ & $\begin{array}{c}\text { Dura- } \\
\text { tion } \\
\text { (in } \\
\text { months) }\end{array}$ & Results \\
\hline 8 & $54, \mathrm{M}$ & $\begin{array}{l}\text { Aortic } \\
\text { stenosis, } \\
\text { hyperpiesis, } \\
\text { anxiety state }\end{array}$ & 4 & 4 & Lost & Improved & 18 & $\begin{array}{l}\text { No pain for } 6 \\
\text { months; then } \\
\text { relapse with } \\
\text { erysipelas }\end{array}$ \\
\hline 9 & $65, M$ & $\begin{array}{l}\text { Reactive } \\
\text { depression }\end{array}$ & 3 & 3 & Lost & Improved & 12 & $\begin{array}{l}\text { No pain for } 6 \\
\text { months ; some } \\
\text { recurrence, but } \\
\text { slighter and less } \\
\text { frequent }\end{array}$ \\
\hline 10 & $49, \mathrm{M}$ & $\begin{array}{l}\text { Hyperpiesis, } \\
\text { anxiety state }\end{array}$ & 2 & 10 & $\begin{array}{c}\text { Much } \\
\text { im- } \\
\text { nroved }\end{array}$ & Improved & 7 & $\begin{array}{l}\text { Occasional slight } \\
\text { pain ; other }\end{array}$ \\
\hline 11 & $51, \mathrm{M}$ & Anxiety state & 2 & 2 & $\begin{array}{l}\text { proved } \\
\text { Im- }\end{array}$ & Improved & 3 & $\begin{array}{l}\text { symptoms better } \\
\text { Much improved }\end{array}$ \\
\hline 12 & $49, \mathrm{M}$ & Hyperpiesis & 13 & 8 & $\begin{array}{l}\text { No } \\
\text { change }\end{array}$ & $\begin{array}{l}\text { No } \\
\text { change }\end{array}$ & 3 & Unchanged \\
\hline
\end{tabular}


Case 11. A man of 51 had had pain that was quantitative to exertion for two months. The onset had been gradual and the pain was not present at rest. The pain was of a squeezing nature and radiated down to both forearms. It was worse on walking uphill and caused him to stop and might last up to two minutes. He had had two slight attacks in bed. The electrocardiogram showed flattening of the $\mathrm{T}$ wave in leads I and IV. During a period of four months, while under treatment as an out-patient, his symptoms became slowly worse. He was, therefore, referred for psychological treatment.

Case 12. A man of 49 had felt slight pain on the left side of the chest for sixteen years. This was at first of the functional type, being left-sided, radiating to the left arm and elbow, but having no relation to exertion or emotion. It might persist for variable lengths of time up to several hours and was not relieved by nitroglycerine. One year previous to examination he had an attack of angina of effort, the pain now being strictly quantitative to exertion and disappearing when exertion slowed down or ceased. Since then he has had angina of effort of a moderate degree. Six years before his systolic blood pressure was 150 , but two years before it had risen to 210/110. On examination the heart showed slight enlargement and there was a systolic murmur at the apex. The blood pressure was 210/138. The electrocardiogram was of the low voltage type and showed some slurring and widening of the QRS complex.

\section{Nature of Psychological Treatment}

Short methods of treatment have been employed in these twelve patients. Each was seen three times a week for an hour. With a few exceptions, the treatment was limited to 60 hours. In some cases, superficial discussion of the current conflict was found to be sufficient to relieve the complaint. In most cases, however, the treatment was conducted along analytical lines, i.e., by free association while lying relaxed on a couch. The aim of such treatment is to help the patient to bring out and to face attitudes, previously unrecognized, which are often strongly emotional. As serious cardiac disorders were present in many of the patients, severe emotional shocks were avoided by keeping interpretation on a comparatively superficial level.

Co-operative patients with a mild or moderate psychological disorder were preferably taken on for treatment. Advanced age, complaints of very long standing, a low standard of intelligence, as well as evidence of a very severe psychological disorder were generally considered as contra-indications. In the group with functional cardiac pain, the psychological diagnosis was labelled as an anxiety state in three patients, as conversion hysteria in three, and as a character disorder in one. Four patients with angina of effort suffered from anxiety states, in two of them with a pronounced obsessional background, and one patient from a reactive depression.

\section{Results on Discharge AND After Follow-up}

\section{Functional Type of Pain}

There will be very little argument about the indication for psychotherapy in patients with cardiac pain of the functional type. Most cardiologists, in 
these cases, employ some form of psychotherapy in an open or concealed form. A glance at Table I shows that, before the beginning of psychological treatment, the patients had received physical treatment of about two or three years-in one case for ten years-without much benefit. The results of psychological treatment can be summarized as follows.

(a) Cardiac Pain. After an average of four months of psychological treatment, six of the seven patients had lost their cardiac pain.

(b) Occupational Efficiency. Three patients who were incapacitated by their complaint, returned to work at the end of the treatment.

(c) Psychological Complaints. Their nervous symptoms, e.g., anxiety, shaking fits, etc., were improved or completely relieved.

(d) Follow-up. In four cases this covered a year or more, and three patients kept up their recovery over the whole period of observation. One was completely restored for six months, but had a relapse in connection with decompensation of the heart ; another, after six months of apparent health, died of acute uræmia. In one, who did very well under treatment, the follow-up is too short. The only patient who did not respond improved during a further course of treatment by Dr. Crichton-Miller, under evipan administration.

\section{Angina of Effort}

Five patients with angina of effort (Table II), after physical treatment without much avail over several years, were taken on for psychological treatment. The results can be summarized as follows.

(a) Cardiac Pain. Two of them, who before treatment were hardly able to walk 100 yards without an attack, were completely relieved from pain at the end of the treatment ; two were improved; and one was not amenable to treatment.

(b) Occupational Efficiency. In two patients occupational efficiency was restored under treatment.

(c) Psychological Complaints. With one exception the patients reported an improvement of their nervous symptoms.

(d) Follow-up. This, as should be anticipated, is less satisfactory than in the functional group. The two patients that lost their pain under treatment remained free for six months; afterwards, one relapsed in connection with erysipelas and the other noted a slight return of pain. "I get the pain only occasionally," he says in a letter, "instead of frequently, and the pain is less when it does occur than it was formerly." The two improved patients kept up their improvement. One did not respond to psychological treatment.

\section{Illustrative CASES}

The points at issue are best illustrated by some typical instances.

Case 1. A big, loquacious, simple-minded man, aged 54, had suffered from attacks of cardiac pain for over three years- " like a knife stabbing." The pain extended along the left arm and was brought on by hard work, excitement, and worry. He was admitted to a hospital, where he was told by one of the physicians that it was angina 
pectoris and that he should avoid any exertion. Since then he had been out of work, resting at home ; he could not walk 100 yards without the pain starting. For the past twelve months he had been sitting in a chair, hardly ever leaving his ground floor room. The physical diagnosis was functional type of cardiac pain.

The youngest of nine children, he was spoilt and pampered as a child. He was his mother's special favourite and from early childhood was over attached to her. $\mathrm{He}$ declined to marry as long as she lived, although she urged him to do so. After her death, when he was 28 , he had a serious nervous breakdown, but married a year later.

He had worked as a parquet-floor layer. When 47 he began to worry more about his work, because there was a new manager who wanted the work to be done more cheaply. As a foreman with a higher wage, he had to work harder than the others and he worried day and night about getting the sack. Very often he could not sleep, and developed headache, giddiness, and morbid fears of crowds and enclosed spaces. "I worried until I collapsed." About two years ago he collapsed at work and immediately afterwards his attacks of heart pain started.

After four months' psychological treatment, his pain disappeared and he returned to his work. Since then he has been free from any complaints. "I walk and enjoy it. My wife grumbles that I walk too quick. I sleep well and awake refreshed. There's a brighter atmosphere all round."

Case 9. A retired schoolmaster, aged 65, a pleasant, friendly, compliant Lancashire man, began to have typical attacks of angina of effort three years ago. He was seen by various heart specialists and told to avoid any exertion. He was unable to walk any distance without attacks of cardiac pain setting in. He had worked his way up from great poverty to be an assistant schoolmaster. In 1928, after quite a successful career, he had to leave as a newly appointed headmaster insisted on his dismissal. After that a hard struggle began ; being advanced in age, he only got temporary posts and eventually, three years ago, found it impossible to get a job at all ; his savings were used up and, unable to support himself, he became entirely dependent on his son. About this time his attacks of angina of effort started.

Superficial discussion of his conflicts was sufficient to relieve his complaints. For six months he remained free from pain, after which slight occasional pain returned.

Case 10. A silversmith, aged 49, attended hospital because of violent attacks of pain in the middle of the chest. He had had these for over two years, brought on by heavy meals, excitement, or the slightest exertion. The diagnosis was angina of effort and hyperpiesis.

He was a courteous, unassuming, little man, self-conscious and blushing easily ; in contrast to his docile and almost timorous behaviour, however, he was harassed by what he called aggressive thoughts. He had impulses to punch people or to spit at them or to cut his wife's throat and, although he never did, was haunted by the fear that he might give way to these impulses and might be locked up and hanged. Further exploration revealed that he had been a most aggressive, troublesome baby but his aggressiveness had been nipped in the bud by a stern, dogmatic father. Rarely, and then only at the peak of resentment, did the patient display aggressiveness in any shape or form.

All through his life he has been rather touchy about any encroachment on his independence, and never liked to be dictated to by anybody. Frequent arguments with his wife arose because he rather emphatically insisted on being "governor in the house." In contrast to this, in recent years he has developed a fear of being thought effeminate and an urge to touch the private parts of a man. Any innuendo in this direction or even discussion of the subject of homosexuality made him blush violently. During the past two years he has been impotent and, in fact, owing to a pronounced fear of going out and of collapse, he has got into a state of complete dependence on his wife. He gave up his job, his wife kept and nursed him and he would never leave the house unless she accompanied him.

Investigation revealed that as the eldest of nine children he had been his mother's 
favourite and, whereas he was over-attached to her, he was scared of, and strongly resentful of, his father. One incident, which he said he had never got over, stood out in his memory. His mother was being confined when he was five or six years old ; he had heard her groaning and wanted to find out why she was doing it but his father pushed him out of the room.

At about 18 he started to masturbate and about the same time to drink. His father was against his drinking and said that he would have to pay for it. After some months he broke down completely ; he cried incessantly, was afraid to go out and developed a fear of insanity. This condition passed off after several weeks. Twelve years ago he had a second nervous breakdown. His fears of going out and of insanity returned and he refrained from sexual intercourse for two years, as he thought this might drive him mad.

Two years ago his mother died and her death initiated his third nervous breakdown. Since then the attacks of cardiac pain, the impotence, and various psychological complaints have developed. "I still want to hang on to my mother and to ask her if to do something will be all right."

As the patient faced up to his previously unrecognized attitudes, the attacks of cardiac pain gradually got less frequent and less severe. He returned to work, his potency was restored, and his nervous symptoms have greatly improved.

\section{Comments AND Conclusions}

The data obtained confirm the view put forward previously, that in cases of functional cardiac pain the pain is nearly always due to transformed anxiety arising from a conflict, unusual in intensity and abnormal in type, between menace to vital feelings and existence on the one side and self-preservation and self-assertion on the other. It is almost a truism to state that those harassed by anxiety are more apt than others to develop cardiac pain, if for some reason or other they are affected by some cardiac disorder. Both in cardiac pain of the functional type and in true angina of effort, relief of underlying anxiety by psychological treatment results in improvement or loss of cardiac pain.

As should be expected, psychotherapy has very little or no effect on the organic cardiovascular disease, the blood pressure and cardiac condition remaining unchanged ; it could, therefore, be objected that removal of pain, as it removes the essential warning not to overdo physical exertion, may be injurious. However, none of the patients with angina of effort died during the prolonged follow-up period and, in fact, as the anginal attacks may in part be due to spasm of the coronary arteries, removal of these attacks may result in an improved circulation in the coronary system.

Summing up, it has been suggested that patients with the functional type of pain and certain patients with angina of effort derive benefit from psychological treatment. The diagnosis of cardiac pain of the functional type is an indication for psychological investigation and possibly for systematic psychotherapy. Only in certain cases of angina of effort, carefully selected as in the cases quoted because of a prominence of emotional elements, is an attempt at psychotherapy justified.

The research was carried out during the tenure of a Research Fellowship granted by the Sir Halley Stewart Trust to one of us (E. W.) and we are very much indebted to the Trust. Our thanks are also due to the Medical Research Council for their grant towards some of the expenses of this investigation. 